\title{
Characterization of Novel Biopolymer Blend Mycocel from Plant Cellulose and Fungal Fibers
}

\author{
Ilze Irbe ${ }^{1, *(\mathbb{D}}$, Inese Filipova ${ }^{1}\left(\mathbb{D}\right.$, Marite Skute $^{1}$, Anna Zajakina ${ }^{2, *} \mathbb{C}$, Karina Spunde ${ }^{2}$ and Talis Juhna ${ }^{3}(\mathbb{D})$ \\ 1 Latvian State Institute of Wood Chemistry, Dzerbenes 27, LV-1006 Riga, Latvia; inese.filipova@inbox.lv (I.F.); \\ polarlapsa@inbox.lv (M.S.) \\ 2 Latvian Biomedical Research and Study Centre, Ratsupites 1 k. 1, LV-1067 Riga, Latvia; \\ karina.spunde@biomed.lu.lv \\ 3 Water Research and Environmental Biotechnology Laboratory, Riga Technical University, P. Valdena 1-303, \\ LV-1048 Riga, Latvia; talis.juhna@rtu.lv \\ * Correspondence: ilzeirbe@edi.lv (I.I.); anna@biomed.lu.lv (A.Z.)
}

Citation: Irbe, I.; Filipova, I.; Skute, M.; Zajakina, A.; Spunde, K.; Juhna, T. Characterization of Novel Biopolymer Blend Mycocel from Plant Cellulose and Fungal Fibers. Polymers 2021, 13, 1086. https:// doi.org/10.3390/polym13071086

Academic Editor: Rafael Antonio Balart Gimeno

Received: 3 March 2021

Accepted: 25 March 2021

Published: 30 March 2021

Publisher's Note: MDPI stays neutral with regard to jurisdictional claims in published maps and institutional affiliations.

Copyright: (c) 2021 by the authors. Licensee MDPI, Basel, Switzerland. This article is an open access article distributed under the terms and conditions of the Creative Commons Attribution (CC BY) license (https:// creativecommons.org/licenses/by/ $4.0 /)$

\begin{abstract}
In this study unique blended biopolymer mycocel from naturally derived biomass was developed. Softwood Kraft (KF) or hemp (HF) cellulose fibers were mixed with fungal fibers (FF) in different ratios and the obtained materials were characterized regarding microstructure, air permeability, mechanical properties, and virus filtration efficiency. The fibers from screened Basidiomycota fungi Ganoderma applanatum (Ga), Fomes fomentarius (Ff), Agaricus bisporus (Ab), and Trametes versicolor ( $\mathrm{Tv}$ ) were applicable for blending with cellulose fibers. Fungi with trimitic hyphal system (Ga, Ff) in combinations with KF formed a microporous membrane with increased air permeability (>8820 mL/min) and limited mechanical strength (tensile index 9-14 Nm/g). HF combination with trimitic fungal hyphae formed a dense fibrillary net with low air permeability (77-115 mL/min) and higher strength 31-36 Nm/g. The hyphal bundles of monomitic fibers of Tv mycelium and Ab stipes made a tight structure with KF with increased strength $(26-43 \mathrm{Nm} / \mathrm{g}$ ) and limited air permeability (14-1630 mL/min). The blends KF FF (Ga) and KF FF (Tv) revealed relatively high virus filtration capacity: the $\log _{10}$ virus titer reduction values (LRV) corresponded to 4.54 LRV and 2.12 LRV, respectively. Mycocel biopolymers are biodegradable and have potential to be used in water microfiltration, food packaging, and virus filtration membranes.
\end{abstract}

Keywords: air permeability; fungal fibers; hemp fibers; microstructure; mechanical properties; mycocel; softwood fibers; virus membrane filtration

\section{Introduction}

The importance of biobased polymers is well known, and much research and development activities concern the use of biobased polymers in science, engineering, and industry. Biopolymers from renewable resources are used in multiple fields, namely health, food, energy, and the environment, due to their intrinsic features, versatility, biocompatibility, and degradability. Besides, the widespread use of biopolymers also addresses concerns about environmental sustainability [1]. As long as biopolymers stand as a sustainable, biodegradable compound, new biopolymer products and materials filled, blended, or reinforced with natural fibers, will predominate with the promise of sustainability benefits [2].

Generally, biobased polymers are classified into three classes: (1) naturally derived biomass polymers such as cellulose, cellulose acetate, starches, chitin, modified starch, etc.; (2) bio-engineered polymers bio-synthesized by using microorganisms and plants such as poly(hydroxy alkanoates (PHAs), poly(glutamic acid), etc.; (3) synthetic polymers produced from naturally derived molecules or by the breakdown of naturally derived macromolecules through the combination of chemical and biochemical processes such as polylactide (PLA), poly(butylene succinate) (PBS), bio-polyolefins, bio-poly(ethylene terephtalic acid) (bio-PET) [3]. The first and second class polymers are biodegradable, they 
allow for more efficient production, which can produce desired functionalities and physical properties, but chemical structure designs have limited flexibility. The third class polymers such as bio-polyolefins and bio-PET are not biodegradable and the only contribution for reducing environmental impact comes from reducing the carbon footprint. The origin of a polymer does not determine its biodegradability; this condition depends on the chemical structure of the polymer [3].

The naturally derived biopolymers, among others, include polysaccharides of plant and fungal origin. Polysaccharides are nontoxic and biodegradable, which increases their potential application in biopolymers. The most used biopolysaccharides are obtained from plant origin (e.g., cellulose), microbial origin (e.g., bacterial cellulose), and animal origin (e.g., chitin/chitosan). Moreover, these natural derivatives present a considerable number of reactive functional groups (e.g., hydroxyl, carboxyl, and amino groups), which significantly increase their applicability through chemical modification or physical blend [1]. Cellulose is the most abundant polysaccharide of natural origin in the world, and is mostly produced by plants. The cellulose chains structure leads to areas of high crystallinity within the polymer and to high stability structures, which as a consequence promote considerable strength, remarkable inertness, and insolubility in water and common organic solvents [4]. In its turn, fungal cell walls share a common chemical structure composed of homo- and heteropolysaccharides, protein, protein-polysaccharide complexes, lipids, melanin, and polysaccharide chains of chitin. Chitin is a biopolymer of $\mathrm{N}$-acetylglucosamine with some glucosamine, which is the main component of the cell walls of fungi and is considered the second most abundant natural polymer after cellulose [5].

Current research in membrane science is now focusing more on biopolymers from natural raw materials with a well-defined structure to develop new membrane materials. In fact, the combination of polysaccharides and proteins is a method frequently used to design blended materials with improved performance regarding swelling, mechanical resistance, and biocompatibility, among other features. The attention has been focused also on membranes based on chitosan blended with other biomacromolecules such as alginate, cellulose, collagen, gelatin, keratin, sericin, and soy protein [6]. Chitin-related materials from fungal sources with focus on nanocomposites and nanopapers have been suggested as greener alternative to synthetic polymers [7]. Fungal chitin-glucan nanopapers have manufactured from chitin nanofibrils, which is a native composite material (chitin-glucan) combining the strength of chitin and the toughness of glucan. These nanopapers showed distinct physico-chemical surface properties, being more hydrophobic than crustacean chitin [8]. Nanopapers from chitin nanofibrils have exhibited tunable mechanical and surface properties with potential use in coatings, membranes, packaging [9] and ultrafiltration of organic solvents and water [10]. Fungal mycelium-nanocellulose has been produced by the agitated liquid culture of a white-rot fungus with nanocellulose as part of the culture media. The obtained biomaterials are suggested for diverse applications, including packaging, filtration, and hygiene products [11].

The literature survey demonstrates that fungal chitin nanofibrils have been used to manufacture nanopapers. Additionally, fungal mycelium has been combined with nanocellulose to obtain a blended biomaterial. However, there are no studies on blended biopolymers from plant cellulose and fungal hyphae. The aim of this study was to develop a novel blended biopolymer from naturally derived biomass that is made of softwood cellulose fibers and fungal fibers (hyphae) and to test it for air permeability, mechanical properties, and virus filtration efficiency. More detailed investigation of specific properties of biomaterial blend containing fungal fibers from basidiomycete Ganoderma applanatum is published in our previous paper [12]. The cellulose fibers from softwood and hemp shives are easily available natural resource. The basidiomycetes selected for this study have shown a high importance in medical and nutritional applications. For example, Ganoderma applanatum has been reported for its phytochemical properties for potential application in nanotechological engineering for clinical use [13]. Fomes fomentarius has been used in a traditional medicine for centuries and is still economically important as 
a source of medicinal and neutraceutical products [14]. Trametes versicolor is known for its general health-promoting effects and is widely employed in traditional medicine [15]. Agaricus bisporus represents the leading position among edible cultivated mushrooms [16].

\section{Materials and Methods}

\subsection{Synthesis of Biopolymers}

The screening of several basidiomycetes was carried out to select the fungal candidates forming homogenous hyphal biomass convenient for biopolymer material development. The fungal biomass was obtained from (1) fruiting bodies of the forest growing species Ganoderma applanatum (Pers.) Pat., Fomes fomentarius (L.) Fr., Lentinus lepideus (Fr.) Fr., Polyporus squamosus (Huds.) Fr., Fomitopsis betulina (Bull.) B.K. Cui, (2) commercially cultivated mushroom stipes of Agaricus bisporus (J.E. Lange) Imbach and (3) mycelium of pure culture strain Trametes versicolor CTB $863 \mathrm{~A}$.

Fungal biomass was kept in $4 \% \mathrm{NaOH}$ solution for $24 \mathrm{~h}$ at a room temperature in order to extract proteins and alkali soluble polysaccharides. Then the samples were washed in tap water and mechanically disintegrated using Blendtec 725 (Orem, UT, USA) at $360 \mathrm{~W}$ for $30 \mathrm{~s}$. Obtained fungal fibers (FF) were dried at room temperature and kept in a dry state until used.

Bleached softwood Kraft fibers (KF) were provided by Metsä Fibre (Äänekoski, Finland) as pressed sheets and used without specific pre-treatment.

Hemp fibers (HF) were obtained from industrial hemp Cannabis sativa (USO-31). After the decortication fibers were treated in $4 \% \mathrm{NaOH}$ solution at $165{ }^{\circ} \mathrm{C}$ for $75 \mathrm{~min}$, then washed with tap water to neutral and refined using Blendtec 725 (Orem, UT, USA) at $179 \mathrm{~W}$ for $7 \mathrm{~min}$ at $1.5 \%$ consistency, dried at room temperature and kept in dry state until used.

For biopolymer blend development, a certain amount (g) of FF in combinations with KF and HF fiber pulp in different mass ratios (50:50 and 33:33:33) was placed in a glass baker and soaked in 1-2 L of distilled water for $8 \mathrm{~h}$, then disintegrated using 75,000 revolutions in the disintegrator (Frank PTI, Laakirchen, Austria). Material sheets were produced according to ISO 5269-2:2004 with a Rapid Köthen paper machine (Frank PTI, Laakirchen, Austria). Grammage (weight per unit area in $\mathrm{g} / \mathrm{m}^{2}$ ) of samples was calculated by dividing the mass with area according to ISO 536:2019. At least five parallel samples at grammage $50 \pm 15 \mathrm{~g} / \mathrm{m}^{2}$ of each composition were prepared.

\subsection{Micromorphology}

The micromorphology was examined by a light microscope (LM) Leica DMLB (Leica Microsystems GmbH, Wetzlar, Germany) at a magnification of 200×. Lactophenol blue solution (Fluka) was used to observe cyanophilic reaction of fungal hyphae. The images were captured by a video camera Leica DFC490 using calibrated image analysis software Image-Pro plus 6.3 (Media Cybernetics, Inc., Rockville, MD, USA).

For scanning electron microscopy (SEM), the surface of samples was coated with gold plasma using a K550X sputter coater (Emitech, Ashford, UK) and examined with Vega TC (Tescan, Brno-Kohoutovice, Czech Republic) with accelerating voltage of $15 \mathrm{kV}$, software 2.9.9.21.

\subsection{Air Permeability}

Air permeability was tested by Bendsen method according to ISO 5636-3:2013 using an air permeability tester 266 (Lorentzen and Wettre, Stockholm, Sweden). Samples were clamped between a metal ring and a rubber gasket and the air flow rate was measured through sample area of $10 \mathrm{~cm}^{2}$ under $1.47 \mathrm{kPa}$ air pressure for $5 \mathrm{~s}$. Commercially available disposable face masks consisting of three layers made of polypropylene spunbondmeltblown-spunbond nonwoven fabrics were tested for air permeability as comparison for developed biopolymer samples. 


\subsection{Mechanical Properties}

For evaluation of tensile properties samples with a width of $1 \mathrm{~cm}$ were prepared with a strip cutter (Frank-PTI, Laakirchen, Austria) and tested according to ISO 1924-1:1992 using a tensile tester vertical F81838 (Frank-PTI, Laakirchen, Austria). Tensile index (Nm/g) was calculated by dividing measured maximum tensile strength $(\mathrm{N} / \mathrm{m})$ by grammage $\left(\mathrm{g} / \mathrm{m}^{2}\right)$ of test sample. Breaking length $(\mathrm{km})$ and stretch $(\%)$ was used as calculated by software of equipment. Burst index $\left(\mathrm{kPa} \mathrm{m}^{2} / \mathrm{g}\right)$ was calculated dividing the measured burst strength $(\mathrm{kPa})$ by grammage $\left(\mathrm{g} / \mathrm{m}^{2}\right)$, where burst strength was measured as hydrostatic pressure necessary to cause rupture in a circular area of a $4 \mathrm{~cm}$ diameter of sample according to ISO 2758:2014 using burst tester (Frank-PTI, Laakirchen, Austria).

\subsection{Virus Preparation and Membrane Filtration Procedure}

The recombinant Semliki forest virus (SFV) pSFVenh/Luc, encoding firefly luciferase gene, was produced as previously described $[17,18]$. The virus-containing cell medium was harvested and concentrated by ultracentrifugation through two sucrose cushions, as previously described [19]. The virus was rapidly frozen and subsequently used as a virus stock. The virus titre expressed in infectious units per $\mathrm{ml}$ (i.u. $/ \mathrm{mL}$ ) was quantified by immunostaining with rabbit polyclonal antibodies specific to the nsp1 subunit of SFV replicase, as previously described [20].

The ability of developed biopolymer materials to retain/remove virus particles was tested using centrifugal filtration test. EMA/CPMP/BWP/268 guidelines were considered for development of virus filtration procedures and calculation of virus reduction values. Two-layer cellulose hygienic paper (AB Grigeo, Vilnius, Lithuania), three-layer cotton mask with antibacterial Silverplus coating (SIA P.E.M.T., Riga, Latvia) and a standard surgical mask type II EN 14,683 (Matopat, Torun, Poland) were used as reference materials.

A $1.5 \times 1.5 \mathrm{~cm}$ sample was cut out from each material, folded in a form of a conical funnel, placed into truncated $1 \mathrm{~mL}$ plastic pipette tip (for better fixation), and subsequently placed into an Eppendorf $1.5 \mathrm{~mL}$ tube as presented in Figure 1.
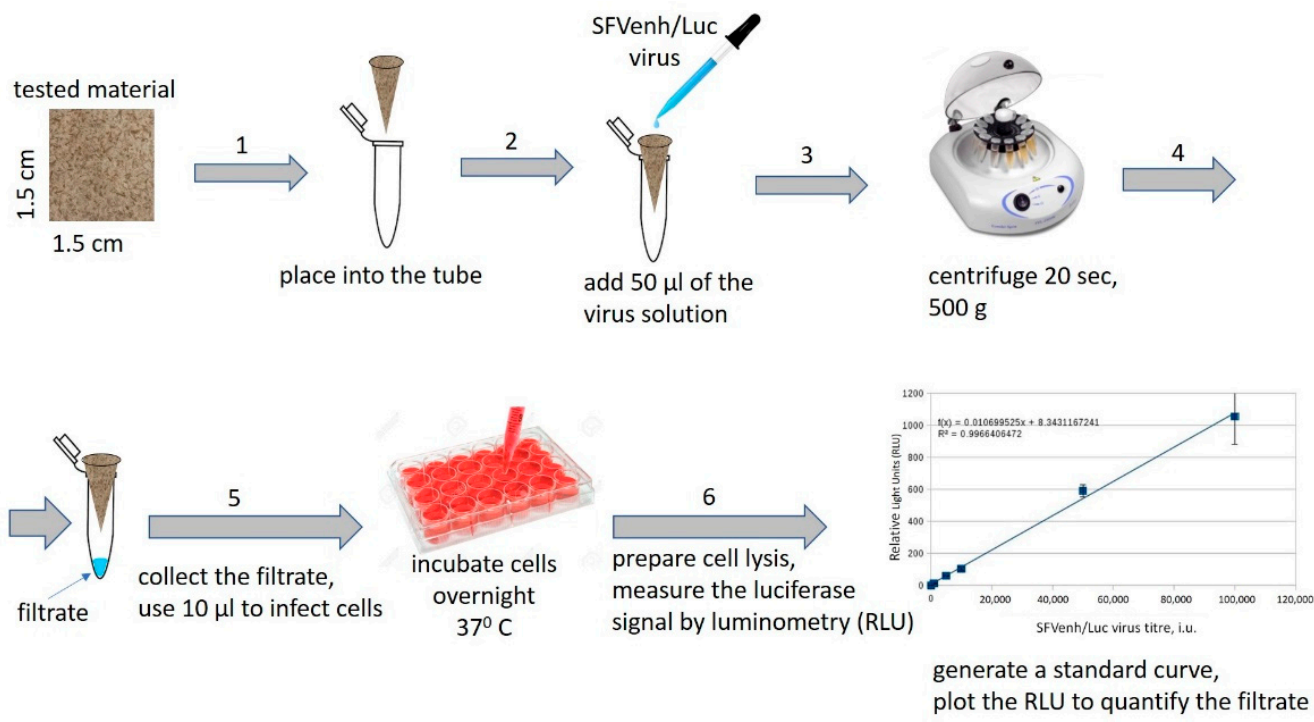

Figure 1. Schematic representation of the virus filtration test (technical details are provided in text). (1) $1.5 \mathrm{~cm} \times 1.5 \mathrm{~cm}$ filter sample is cut out from each material, folded into the form of a conical funnel, and placed into a $1.5 \mathrm{~mL}$ tube; (2) $50 \mu \mathrm{L}$ of recombinant Semliki forest virus (SFV)-enh/Luc virus solution (107 i.u./mL) is added into the cone; (3) the tube is centrifuged to allow the virus to pass through the material; (4) the filtrate (indicated by arrow) is collected; (5) the filtrated is diluted and used for cell infection in a 24-well cell culture plate; (6) after overnight incubation of the plate the cell lysates are prepared and the virus infection is measured by detection of the luciferase activity in infected cells (luminometry). The cell infection with the standard dilutions of the virus is used to generate a standard curve and to calculate the amount of virus in the filtrate. 
$50 \mu \mathrm{L}$ of recombinant SFVenh/Luc virus solution with a titer of $10^{7}$ infectious units per milliliter (i.u./mL) were poured into each cone containing the test material. The tubes were then centrifuged for $20 \mathrm{~s}$ at $500 \times g$ (3500 rpm) by FVL-2400N Combi-Spin, MiniCentrifuge/Vortex (Biosan, Riga, Latvia) to allow the liquid to pass (filtrate) through the material under low pressure conditions. The filtrated virus samples were collected (at least $20 \mu \mathrm{L}$ each) and used for BHK-21 cell infection in 24-well plate as previously described [18]. Briefly, $10 \mu \mathrm{L}$ of the virus sample in duplicate was mixed with $190 \mu \mathrm{L}$ PBS (containing $\mathrm{M}^{2+}$ and $\mathrm{Ca}^{2+}$ ) and incubated with BHK-21 cells for $1 \mathrm{~h}$ at $37^{\circ} \mathrm{C}, 5 \% \mathrm{CO}_{2}$, then $800 \mu \mathrm{L}$ of BHK medium ( $1 \%$ fetal bovine serum) was added. In parallel, standard dilutions of the SFVenh/Luc virus in a range $1 \times 10^{3}-5 \times 10^{5} \mathrm{i}$.u. $/ \mathrm{mL}$ per well were generated and used for BHK-21 cell infection in duplicate in the 24-well plate. The cells were incubated overnight at $37^{\circ} \mathrm{C}, 5 \% \mathrm{CO}_{2}$ to allow complete cell infection to complete and expression of firefly luciferase gene.

To quantify the virus titer in filtered samples the relative luminescence units (RLU) were measured in cell lysates and the respective values were plotted on the standard curve with serial SFVenh/Luc virus dilutions. The RLUs were measured by the Luciferase assay (Promega, Madison, WI, USA), as recommended by manufacturer. Briefly, the cell medium was removed, and the cells (24-well) were lysed in $100 \mu \mathrm{L}$ of the Cell Culture Lysis buffer (Promega, Madison, WI, USA), centrifuged at $600 \mathrm{cfr}$ for $5 \mathrm{~min}$, and $1 \mu \mathrm{L}$ of the cell lysate was used immediately to measure the luciferase enzymatic activity by luminometer Luminoskan Ascent (Thermo Scientific, Loughborough, UK). The cell infection was done in duplicate in each independent experiment. Two independent experiments were performed with each sample (repeats). The virus titer standard curve was generated in each experiment and the negative control signal (RLU of uninfected cells) was subtracted from all values. The $\log _{10}$ reduction value (LRV) represents the difference between loaded and eluted virus infectious units per $\mathrm{ml}$, and respectively was calculated according to the following equation:

$\mathrm{LRV}=\left[\log _{10}\right.$ (virus titer before filtration) $-\log _{10}$ (virus titer after filtration) $]$.

Statistical analysis of obtained results was performed using an Excel 2016 MSO data statistical analysis tool.

\section{Results and Discussion}

The fruiting bodies of L. lepideus, P. squamosus, and F. betulina formed gelatinous biomass in $\mathrm{NaOH}$ solution which was unusable for further experiments. FF were successfully separated from the biomass of fungi G. applanatum, F. fomentarius, A. bisporus, and T. versicolor and integrated in biopolymer compositions with softwood and hemp cellulose fibers.

\subsection{Morphological Characterization}

The microscopic structure of mycocel biopolymer blends and macrostructure of developed materials is shown in Figure 2.

Kraft fibers, hemp fibers, and fungal fibers were most likely physically bound together making a net of the biopolymer material. The fungal fibers separately or in bundles were randomly distributed within the net of cellulose fibers. The structure of materials was affected by individual properties of fibers. The size of Kraft fibers was average $2 \mathrm{~mm}$ in length and $30 \mu \mathrm{m}$ in width. Hemp fibers were $1 \mathrm{~mm}$ long and 10-20 $\mu \mathrm{m}$ wide with a net of microfibers $(2-5 \mu \mathrm{m})$. Fungal fibers from fruiting bodies of poroid species (G. applanatum, F. fomentarius) (Figure 2a,b) were 2-7 $\mu \mathrm{m}$ across. The fibers of $T$. versicolor mycelium were 2-3 $\mu \mathrm{m}$ wide (Figure 2c). The stipes of mushroom A. bisporus were composed of swollen hyphae, ascending 7-20 $\mu \mathrm{m}$ across (Figure 2d). 

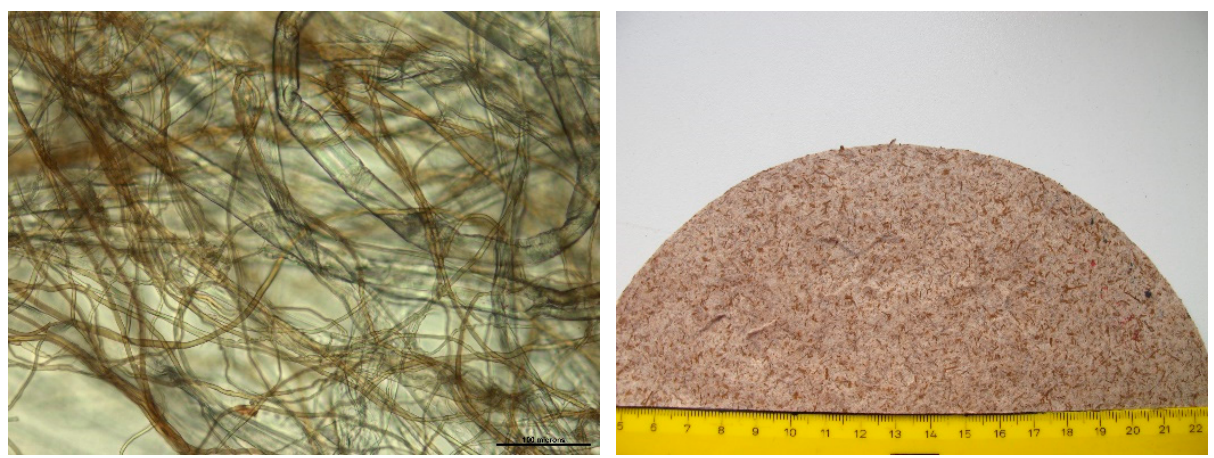

(a)
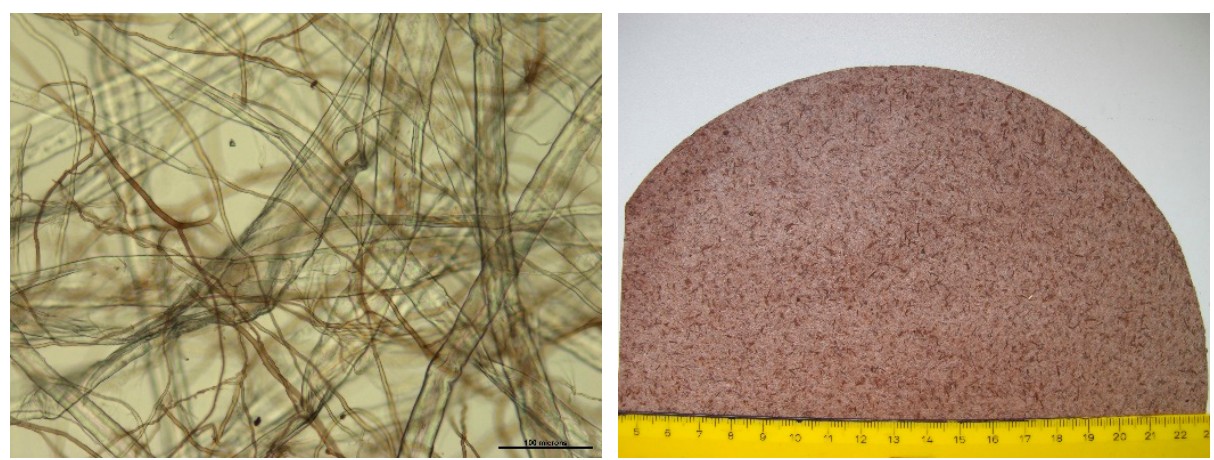

(b)
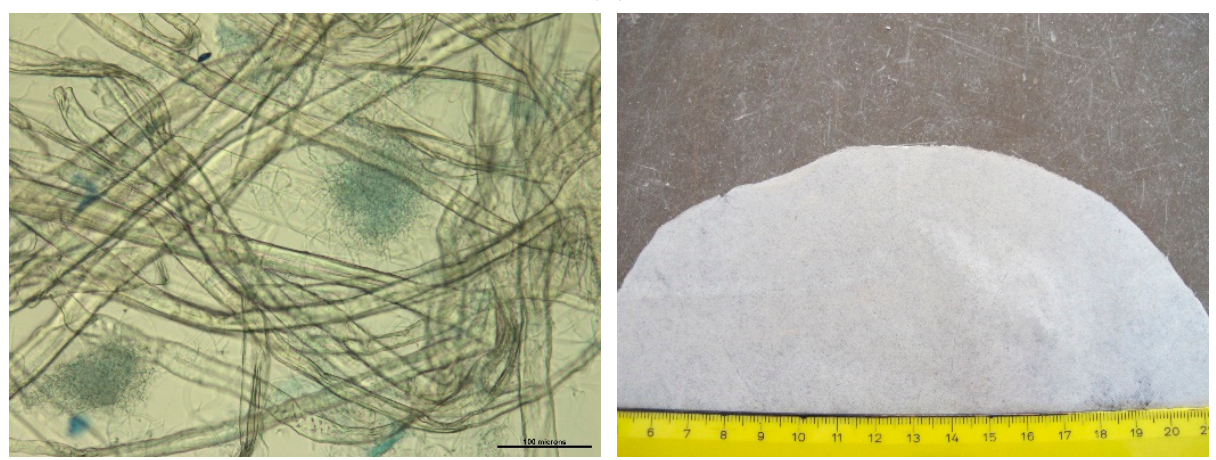

(c)
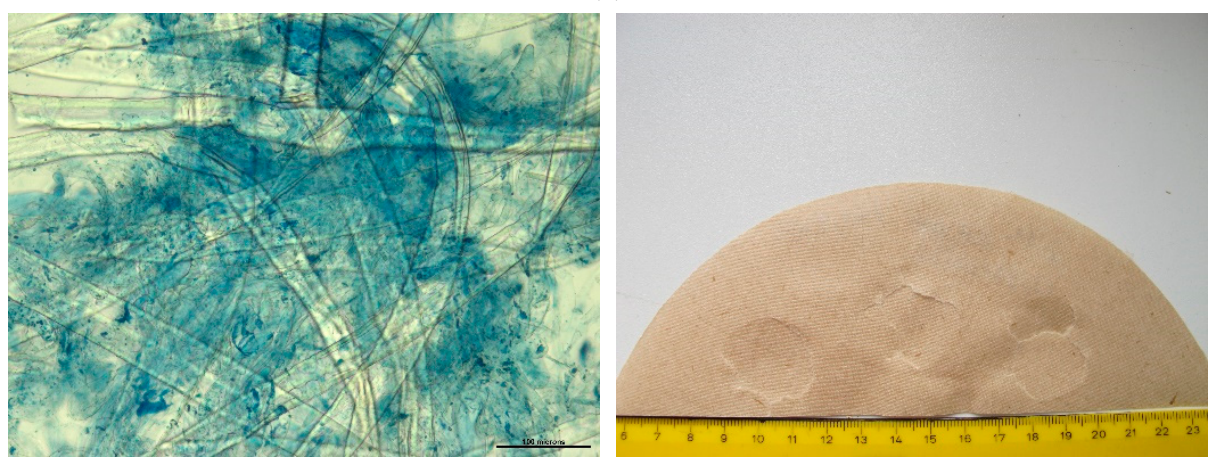

(d)

Figure 2. Cont. 

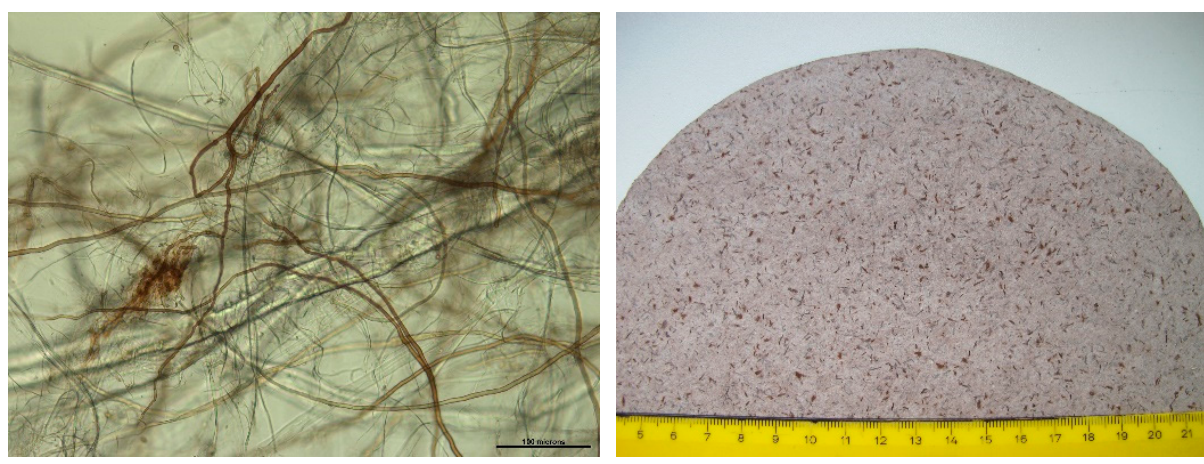

(e)

Figure 2. Microstructure (left column) and macrostructure (right column) of mycocel biopolymer compositions made of Kraft fibers (KF), hemp fibers (HF), and fungal fibers (FF): (a) KF FF (Ff); (b) KF FF (Ga); (c) KF FF (Tv); (d) KF FF (Ab); (e) KF HF FF (Ga). Microimages show flat hemp and softwood fibers $(10-30 \mu \mathrm{m})(\mathbf{a}-\mathbf{e})$ and narrow fungal fibers $(2-7 \mu \mathrm{m})$ of polypores $(\mathbf{a}-\mathbf{c}, \mathbf{e})$ and swollen hyphae $(7-20 \mu \mathrm{m})$ of agaric (d). LM, 200×. Bar $=100 \mu \mathrm{m}$.

The hyphae of basidiomycetes (primarily poroid species) are divided in three main types: generative, binding, and skeletal hyphae with key differences in cell wall thickness, internal structure, and branching characteristics. Monomitic species comprise only generative hyphae, dimitic species comprise two hyphal types (usually generative and skeletal) and trimitic species contain all three hyphal types [21].

The fungal fruiting bodies under this study, namely, G. applanatum and F. fomentarius, had trimitic hyphal system. Depending on the species, the generative hyphae were $2-5 \mu \mathrm{m}$, skeletal hyphae 3-7 $\mu \mathrm{m}$ and binding hyphae $2-4 \mu \mathrm{m}$ across (Figure $2 \mathrm{a}, \mathrm{b}$ ). In the case of poroid species $T$. versicolor, the mycelium of pure culture strain consisted of thin-walled generative hyphae, while hyphae of agaric $A$. bisporus were flat and swollen. The fibers of two later species formed dense hyphal bundles among the cellulose fibers. These can be observed in Figure 2c,d where cyanophilic reaction turned hyaline hyphae of Tv and $\mathrm{Ab}$ blue after staining. The trimitic species $\mathrm{Ga}$ and Ff presented brown pigmented hyphal network (Figure 2a,b,e). The pigmented layer within the hyphal cell wall is likely crosslinked to polysaccharides and has a mesh-like structure with pores, through which small and large molecules can penetrate into cells. Pigment melanin is believed to enhance the strength of the cell wall and has antioxidant properties and propensity to bind to a variety of substances [22].

SEM micrographs (Figure 3) support the findings of LM and display a detailed ultrastructure of the raw materials and mycocel biopolymer blends. Fiber orientation appeared randomly distributed, entangled fibers were physically bound together with $\mathrm{H}$ bonds, forming non-oriented, multi-layered net. Kraft fibers (Figure 3a) were flattened and made a microporous network. Similarly, the fungal fibers Ga (Figure 3c) formed a network of microporous structures. Hemp material (Figure $3 b$ ) displayed a dense structure composed of flat fibers and thin microfibers.

The microstructure of mycocel biopolymers was affected by individual properties of raw materials. The structure of KF FF (Ga) (Figure 3d) was determined by individual properties of Kraft fibers and fungal fibers. Distribution FF among the flattened KF favoured formation a loose microporous structure of the material. The structure of biopolymer HF FF (Ga) was affected by a dense network of variable diameter hemp fibers (Figure 3e). The FF were incorporated in a tight HF network of microfibers forming a compact structure with decreased porosity. The surface of KF HF FF (Ga) material (Figure 3f) displayed dense areas of hemp fibers and Kraft fibers with few areas of loose fungal fibers. The porosity and the tortuosity fractal dimension are two critical parameters to determine the permeability. It is reported [23] that increase in the tortuosity fractal dimension leads to decrease in the dimensionless permeability and absolute permeability; an increase in the porosity increases 
the dimensionless permeability; increase in the fiber diameter yields an increase in the absolute permeability.

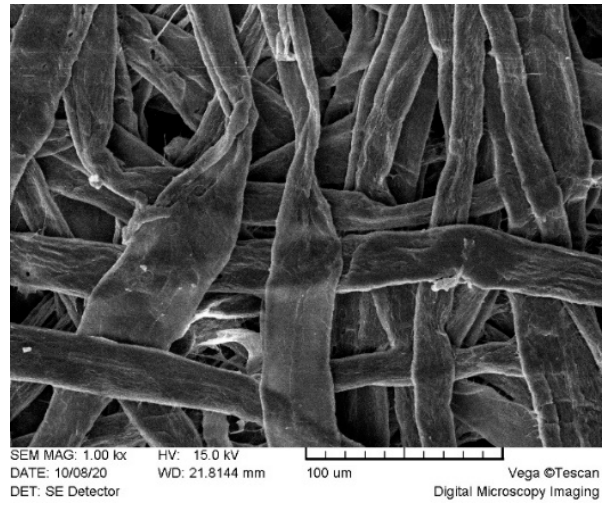

(a)

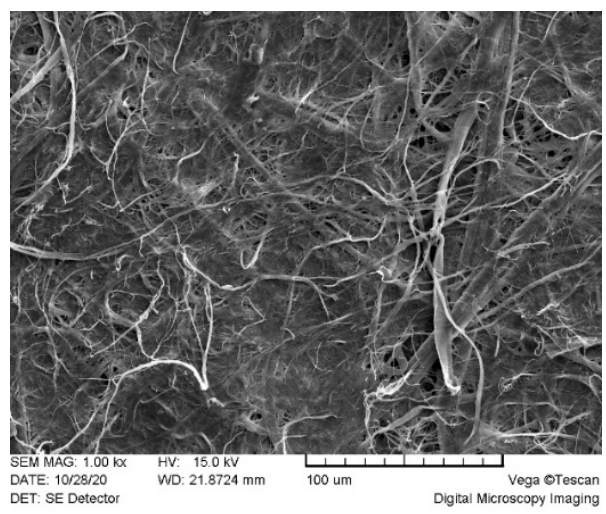

(b)

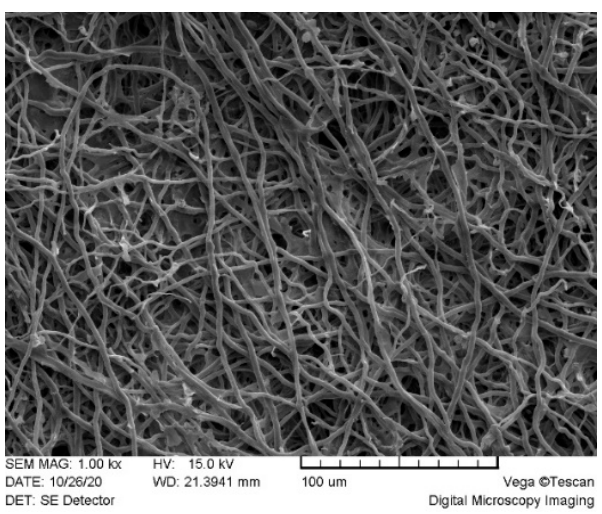

(c)

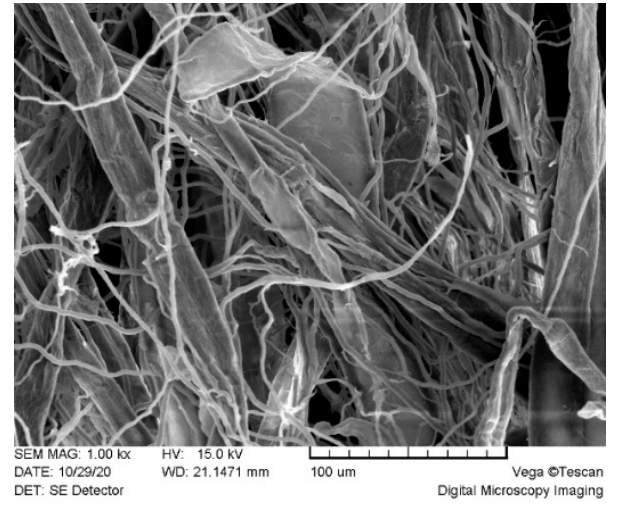

(d)

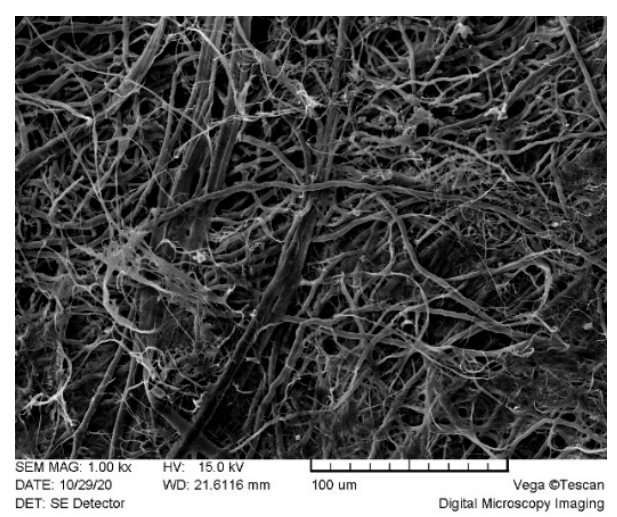

(e)

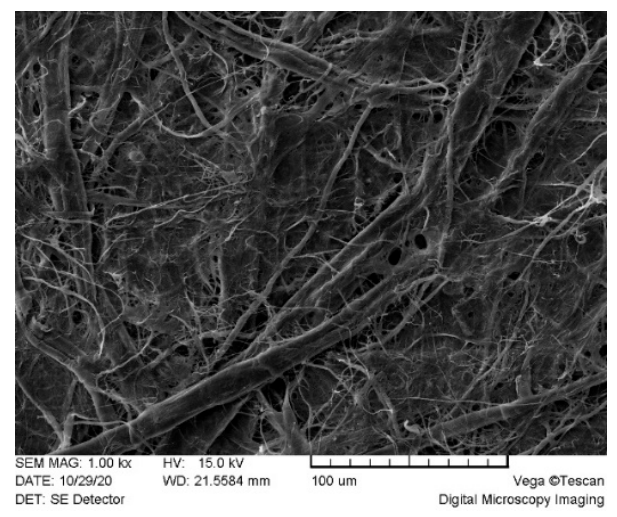

(f)

Figure 3. Ultrastructure of raw materials (left column) from (a) Kraft fibers (KF), (b) hemp fibers (HF), and (c) fungal fibers (FF Ga), and mycocel biopolymer compositions (right column): (d) KF FF (Ga); (e) HF FF (Ga); (f) KF HF FF (Ga). SEM, 1000×. Bar $=100 \mu \mathrm{m}$.

\subsection{Air Permeability}

The air permeability results were supported by microscopy findings. Mycocel biopolymer compositions had significant variations in air permeability properties starting from almost non-air permeable ones to materials with air permeability above measuring limit of device, which was $8820 \mathrm{~mL} / \mathrm{min}$ (Table 1). The fungal type of hyphae had a significant effect on results. Biopolymer blends having F. fomentarius (Ff) or G. applanatum (Ga) trimitic hyphal system in combination with Kraft fibers (KF FF (Ff) and KF FF (Ga)) had the highest 
air permeability $>8820 \mathrm{~mL} / \mathrm{min}$. Biopolymers consisting of cellulose fibers (KF and $\mathrm{HF}$ ) and A. bisporus (Ab) hyphae had the lowest air permeability $14.1 \mathrm{~mL} / \mathrm{min},<1 \mathrm{~mL} / \mathrm{min}$ and $7.5 \mathrm{~mL} / \mathrm{min}$ for KF FF $(\mathrm{Ab})$, HF FF (Ab), and KF HF FF (Ab), respectively.

Table 1. Mechanical and air permeability properties of mycocel biopolymer materials (KF = Kraft fibers; HF = hemp fibers; $\mathrm{FF}=$ fungal fibers; $\mathrm{Ga}=\mathrm{G}$. applanatum; $\mathrm{Ab}=$ A. bisporus; $\mathrm{Tv}=$ T. versicolor $; \mathrm{Ff}=$. fomentarius $)$. The marked $\left({ }^{*}\right)$ samples have been described previously [12].

\begin{tabular}{|c|c|c|c|c|c|c|}
\hline Sample & $\begin{array}{c}\text { Tensile Index, } \\
\text { Dry Nm/g }\end{array}$ & $\begin{array}{l}\text { Tensile Index, } \\
\text { Wet } \mathrm{Nm} / \mathrm{g}\end{array}$ & $\begin{array}{l}\text { Burst Index } \\
\mathrm{kPa} \mathrm{m}^{2} / \mathrm{g}\end{array}$ & $\begin{array}{c}\text { Breaking Length } \\
\text { km }\end{array}$ & $\begin{array}{l}\text { Stretch } \\
\%\end{array}$ & $\begin{array}{c}\text { Air Permeability } \\
\mathrm{mL} / \mathrm{min}\end{array}$ \\
\hline $\mathrm{KF}^{*}$ & 16.9 & 0.8 & 1.0 & 1.7 & 0.9 & 8275 \\
\hline $\mathrm{HF}^{*}$ & 60.4 & 10.9 & 4.6 & 6.1 & 3.4 & 32 \\
\hline $\mathrm{FF}(\mathrm{Ga}) *$ & 8.2 & - & 0.9 & 0.8 & 2.0 & 6935 \\
\hline $\mathrm{KF} F F(\mathrm{Ga})$ * & 13.9 & 1.3 & 1.0 & 1.4 & 2.0 & $>8820$ \\
\hline $\operatorname{HF} F F(G a) *$ & 30.8 & - & 2.1 & 3.1 & 3.4 & 77 \\
\hline HF FF (Ab) & 32.5 & 5.3 & 2.0 & 3.3 & 0.7 & $<1$ \\
\hline $\mathrm{KF} \operatorname{HF} \mathrm{FF}(\mathrm{Ga}) *$ & 35.9 & 1.9 & 2.8 & 3.7 & 3.9 & 115 \\
\hline KF FF (Tv) & 26.5 & 2.4 & 2.0 & 2.7 & 2.0 & 1630 \\
\hline KF FF (Ff) & 8.9 & - & 1.5 & 0.9 & 1.1 & $>8820$ \\
\hline $\mathrm{KF} F \mathrm{~F}(\mathrm{Ab})$ & 43.5 & 3.0 & 1.9 & 4.4 & 1.0 & 14.1 \\
\hline KF HF FF (Ab) & 46.0 & 3.0 & 2.4 & 4.7 & 1.6 & 7.5 \\
\hline
\end{tabular}

It should be noted that materials with HF in their composition had the lowest air permeability numbers because of high Shopper Riegler freeness of hemp cellulose fiber $\left(91.5^{\circ} \mathrm{SR}\right)$ [12], which led to high bonding and tight networks of fibers (Figure $3 \mathrm{~b}$ ). The bonding of cellulose fibers is based primarily on hydrogen bonding between hydroxyl functional groups during close contacting of fibers [24]. The same bonding theory can be attributed to investigated mycocel biopolymer materials, since cellulose and chitinthe main constituent of hyphae-are biopolymers and have similar polysaccharide chain structure with the main difference being the replacement of one of the three hydroxyl groups with acetyl amine group in chitin monomeric unit [25]. The ability of functional groups of hyphal polysaccharides to make hydrogen bonding with cellulose fibers is one of the key elements of network formation in investigated mycocel materials. Furthermore, better bonding leads to a more compact packing of fibers and lower free volumes associated with lower air permeability [26], which can be seen in the cases of biopolymer blends with $\mathrm{Tv}$ mycelial and Ab stipe fibers. The higher numbers of air permeability showed lower ability of Ga and Ff hyphae to get involved in the network of cellulose fibers through hydrogen bonding. It can be explained by presence of non-polysaccharidic substances, such as pigments, which were indicated by the dark color of fruiting bodies and isolated hyphae from $\mathrm{Ga}$ and $\mathrm{Ff}$.

Mycocel blends with higher air permeability have potential for using as gas permeable membranes, for example, as biobased filter layer in face masks. Disposal medical face masks, used as reference material, correspondingly showed high air permeability above $8820 \mathrm{~mL} / \mathrm{min}$, therefore only KF FF (Ga) and KF FF (Ff) are appropriate for this application. Blends with very low air permeability, such as those containing Ab hyphae can be used in applications, where high air or gas barrier properties are important, for example, food packaging materials [27].

\subsection{Mechanical Properties}

Comparison of cellulose and fungal fiber biopolymers showed significant differences among different fungal species and hyphal types regarding their effects on mechanical properties of investigated materials (Table 1 ). It was possible to produce a pure fiber material from G. applanatum $(\mathrm{Ga})$ and A. bisporus $(\mathrm{Ab})$ biomass, however $\mathrm{FF}(\mathrm{Ga})$ material had a rather low tensile index $8.2 \mathrm{Nm} / \mathrm{g}$, but FF (Ab) material was too fragile for handling and it was not possible to measure mechanical properties. When compare two-component blends of Kraft fibers and fungal fibers, the best results were obtained in the case of KF FF 
$(\mathrm{Ab})$ and $\mathrm{KF} F F(\mathrm{Tv}), 32.5$ and $26.5 \mathrm{Nm} / \mathrm{g}$, respectively, which is by $92 \%$ and $57 \%$ more than tensile index measured for material containing only KF. However, addition of G. applanatum (Ga) or F. fomentarius ( $\mathrm{Ff}$ ) fibers to cellulose fibers decreased mechanical strength by $18 \%$ for KF FF (Ga) and by 48\% for KF FF (Ff) if compare with pure KF. This can be explained by specific character of $\mathrm{Ab}$ and $\mathrm{Tv}$ hyphae which formed a dense microstructure with cellulose fibers increasing the mechanical strength of material. It is reported [28] that generative hyphae alone (monomitic hyphal system), which are hollow and contain cytoplasm, are suggested to provide limited mechanical performance, with binding hyphae (dimitic and trimitic hyphal systems) responsible for material strength. Contrary, our results showed that the trimitic hyphal system of fungi Ga and Ff did not favor an improvement of mechanical properties of mycocel compositions. Lower mechanical performance of Ga and Ff hyphae containing materials can be explained also by the aspects mentioned in description of air permeability properties and are related to lower ability for bonding with cellulose caused by presence of non-polysaccharidic substances and lower amount of hydrogen bonds formed. It is known that fiber to fiber bonding or bonding strength is directly related to mechanical strength of cellulose fiber-based materials and can be evaluated using results of mechanical tests [29].

Tensile index was almost threefold higher in wet stage when compare KF and KF $\mathrm{FF}(\mathrm{Ab})$ showing the ability of $\mathrm{Ab}$ hyphae to significantly improve the strength of fiber material in wet conditions. Two-component blends consisting of hemp fibers and fungal fibers HF FF were produced using hemp cellulose and $\mathrm{Ga}$ or $\mathrm{Ab}$ fibers. It must be noted that highly fibrillated hemp fibers with freeness $91.5^{\circ} \mathrm{SR}$ used in the research, had the most significant effect on the mechanical strength of all investigated materials. Furthermore, pure HF material had the highest tensile index among all the tested materials by reaching $60.4 \mathrm{Nm} / \mathrm{g}$. Addition of hyphae significantly decreased tensile index reaching $30.8 \mathrm{Nm} / \mathrm{g}$ in the case of HF FF (Ga) and $32.5 \mathrm{Nm} / \mathrm{g}$ in the case of HF FF (Ab). When compare threecomponent blends KF HF FF, here also Ab hyphae showed the highest effect on mechanical properties of composites by KF HF FF (Ab) reaching tensile index $46 \mathrm{Nm} / \mathrm{g}$, while KF HF FF (Ga) reached $35.9 \mathrm{Nm} / \mathrm{g}$. Overall, A. bisporus $(\mathrm{Ab})$ and T. versicolor $(\mathrm{Tv})$ fibers showed higher potential as component of biopolymer for improving the mechanical properties of cellulose fiber-based materials, whether they consist of wood or hemp cellulose fibers. Biopolymers containing Ga hyphae demonstrated the highest flexibility measured as percentage elongation or stretch. HF FF (Ga) and KF HF FF (Ga) samples reached $3.4 \%$ and $3.9 \%$ stretch, while other composites had numbers equal or below $2.0 \%$.

Mechanical performance of materials was evaluated also by measuring burst index, which is the hydrostatic pressure necessary to cause rupture in a circular area of a given diameter and tells how much pressure material can tolerate before rupture. Three component blends showed the highest burst index $2.8 \mathrm{kPa} \mathrm{m}^{2} / \mathrm{g}$ and $2.4 \mathrm{kPa} \mathrm{m}^{2} / \mathrm{g}$ for KF FF FF $(\mathrm{Ga})$ and KF HF FF $(\mathrm{Ab})$ respectively, indicating the prevalence of fiber diversity presented in mechanical blend. If two-component blends are compared, $\mathrm{Tv}$ and $\mathrm{Ab}$ containing KF FF materials have higher results than $\mathrm{Ga}$ and $\mathrm{Ff}$ containing ones. Breaking length is used to characterize inherent strength of material and is defined as the length of imaginary material strip, if suspended vertically from one end, would break by its own weight. Numeric values of breaking length of biopolymer blends were in direct correlation with tensile strength values showing the predominance of $\mathrm{Ab}$ and $\mathrm{Tv}$ containing materials and lower results in $\mathrm{Ga}$ and $\mathrm{Ff}$ containing materials. Mechanical properties of disposal medical face masks layers were not possible to measure according to the standard and device used for biopolymer blends testing, however apparently they are less strong than materials of biopolymer blends.

\subsection{Virus Filtration Properties}

In order to evaluate the filtration properties of the experimental biomaterials, the recombinant Semliki forest virus (SFV) was applied, which belongs to the Togaviridae family of enveloped RNA viruses $(60-70 \mathrm{~nm}$ in diameter) structurally similar to human 
pathogenic viruses such as influenza and coronaviruses. The test system was based on a safe replication deficient SFV vector (pSFVenh/Luc), allowing to perform one round cell infection to be performed with precise quantification of the virus filtration rates using rapid measurement of luciferase activity in infected cells.

The efficiency of the SFV/enhLuc virus filtration through the tested materials are summarized in Table 2. The efficient virus retention properties were observed both for raw materials (Kraft fibers, hemp fibers, and fungal fibers $\mathrm{Ga}$ ) and mycocel blends KF FF (Ga) and KF FF (Tv), which revealed very low virus permeability rates $(<2 \%)$. Cellulose hygiene paper also showed the ability to retain the virus, albeit with lower efficiency (the permeability $<30 \%$ ) comparing to cellulose containing biopolymers. The properties of cellulose materials are determined by production technology and additives which can result in lower mechanical strength, density, and virus filtering efficiency as observed in the case of hygiene paper. Regarding the reference materials, i.e., face masks, the highest virus permeability was observed for the tested surgical mask $(>92 \%)$ and hydrophobic outer layer of the cotton mask $(>70 \%)$, whereas the Silverplus layer retained the virus significantly (the permeability $<1 \%$ ).

Table 2. SFV1enh/Luc recombinant virus titer change after pressure filtration through experimental materials $(\mathrm{KF}=\mathrm{Kraft}$ fibers; $\mathrm{HF}=$ hemp fibers; $\mathrm{FF}=$ fungal fibers; $\mathrm{Ga}=\mathrm{G}$. applanatum; $\mathrm{Tv}=$ T. versicolor).

\begin{tabular}{|c|c|c|c|c|}
\hline Sample & $\begin{array}{c}\text { Virus Titer } \\
\text { i.u./mL } \pm \text { SD }\end{array}$ & $\begin{array}{l}\text { Virus Titer } \\
{\left[\log _{10}\right]}\end{array}$ & $\begin{array}{c}\log _{10} \text { Reduction } \\
\text { Value } \\
\text { LRV }\end{array}$ & $\begin{array}{c}\text { Virus Amount after Filtration } \\
\text { Relative to Nonfiltered Control } \\
\%\end{array}$ \\
\hline Non-filtered virus & $(1 \pm 0.066) \times 10^{7}$ & 7.00 & - & 100 \\
\hline Surgical mask (all layers) & $(8.28 \pm 0.066) \times 10^{6}$ & 6.92 & 0.08 & 92.63 \\
\hline Cellulose hygienic paper & $(2.66 \pm 0.076) \times 10^{6}$ & 6.42 & 0.58 & 27.05 \\
\hline $\mathrm{KF}$ & $(1.43 \pm 0.413) \times 10^{4}$ & 4.16 & 2.84 & 0.16 \\
\hline KF FF (Ga) & $(2.86 \pm 0.076) \times 10^{2}$ & 2.46 & 4.54 & 0.00 \\
\hline KF FF (Tv) & $(7.66 \pm 0.791) \times 10^{4}$ & 4.88 & 2.12 & 0.78 \\
\hline $\mathrm{FF}(\mathrm{Ga})$ & $(2.25 \pm 1.460) \times 10^{4}$ & 4.35 & 2.65 & 0.26 \\
\hline $\mathrm{HF}$ & $(6.27 \pm 2.120) \times 10^{3}$ & 3.80 & 3.20 & 0.08 \\
\hline $\begin{array}{l}\text { Cotton outer layer } \\
\text { (hydrophobic) }\end{array}$ & $(7.21 \pm 0.0330) \times 10^{6}$ & 6.86 & 0.14 & 73.44 \\
\hline $\begin{array}{l}\text { Cotton Silverplus middle } \\
\text { layer }\end{array}$ & $(2.52 \pm 3.350) \times 10^{3}$ & 3.40 & 3.60 & 0.03 \\
\hline Cotton inner layer & $(7.31 \pm 1.300) \times 10^{5}$ & 5.86 & 1.14 & 7.44 \\
\hline
\end{tabular}

According to EMA guidelines (CPMP/BWP/268/95, European Medicines Agency) the $\log _{10}$ reduction value (LRV) is an important parameter to quantify the virus reduction capacity. Only the LRV > 4 is considered as a "very high" virus reduction potential. In this study, the biopolymer KF FF (Ga) demonstrated sufficiently high virus reduction capacity (4.54 LRV). Remarkably, the silver containing cotton layer of the commercial mask also showed efficient virus removal properties (3.6 LRV), which can be related to the viricidal capacity of the immobilized silver nanoparticles [30].

Due to safety aspects, handling of human viruses is a labor-intensive and timeconsuming process. In this study, we have established a protocol for a relatively simple virus filtration method, which is based on replication deficient SFV vector encoding firefly luciferase used for rapid virus quantification. The proposed method can be efficiently applied for primary screening of virus filtration properties of the membranes.

The mechanisms underlying the membrane filtration of viruses include size exclusion and/or adsorptive interactions (e.g., hydrophobic/hydrophilic and electrostatic interactions) between virus envelope and membrane compounds [31]. The diameter of the virus particles is much smaller than the pore size of the tested membranes. Therefore, the adsorptive interactions can be considered as the main mechanism of filtration in the tested system. A surgical mask, which is made of hydrophobic polypropylene layers, did not adsorb aqueous virus containing solution, resulting in low virus re- 
tention values (Table 2). Practically, the surgical masks serve as a barrier to aqueous aerosol and are designed to block direct fluid entry into the wearer's respiratory tract and mostly act as a repellent of the water-based liquids [32]. In contrast to surgical mask and tested cotton mask, the row fiber materials and mycocel blends exhibited hygroscopic properties and showed the ability to binding, or adsorption of SFV particles. A high virus filtration capacity of mycocel biopolymer blends might be attributed to the structural properties of the fungal cell wall as an insoluble polysaccharide-based sorbent. The fungal polysaccharides possess direct virus inactivation properties as shown for several highly pathogenic human viruses, including human immunodeficiency virus, herpes simplex virus, etc. [33]. The application of mycocel-based filters alone or in combination with polypropylene-based layers can represent an advanced individual respiratory protective device against airborne pathogens. Furthermore, chitin, one of the main polymers of fungal cell walls, is widely used for controlled drug delivery systems, protein and enzyme carriers, and packaging materials, based on its natural antimicrobial activity. Chitin and its derivatives (e.g., chitosan) have many useful properties that make them suitable for a wide variety of biomedical applications. Their products are known to be antibacterial, antifungal, antiviral, nontoxic, and nonallergic [34]. Therefore, the proposed mycocel-based biopolymers are promising multifunctional materials for biomedical and bioengineering applications.

\section{Conclusions}

A novel mycocel biopolymer from naturally derived biomass of plant cellulose fibers and fungal fibers (hyphae) was developed and characterized regarding its air permeability, mechanical properties, and virus filtration efficiency.

Air permeability and mechanical properties of mycocel biopolymer blends were affected by microstructural features of raw materials. Highly fibrillated hemp fibers had the most significant effect on the mechanical strength while Kraft fibers revealed increased air permeability. The ability of functional groups of hyphal polysaccharides to make hydrogen bonding with cellulose fibers was one of the key elements of network formation which determined biopolymer properties. The loose fiber net of trimitic fungal species G. applanatum and F. fomentarius with incorporated Kraft fibers formed a microporous structure of mycocel blends with improved air permeability (>8820 m/min) and limited mechanical properties in comparison with individual raw fibers. A. bisporus and T. versicolor fibers showed higher potential as components of biopolymer for improving the mechanical properties of cellulose fiber-based materials, whether they consist of wood or hemp cellulose fibers.

Virus testing provided promising results regarding virus filtration efficiency of biopolymer blends. Mycocel biopolymer KF FF (Ga) demonstrated sufficiently high virus reduction capacity (4.54 LRV) than surgical mask and outer and inner layers of commercial face mask. Feasibly, the adsorptive interactions can be considered as the main mechanism of filtration in tested system.

The natural, biodegradable mycocel blends have a potential for use in biomaterial membranes depending on the target application. Blends with higher air permeability and virus filtration efficiency have potential for being used as gas permeable membranes, for example, as biobased filter layer in face masks. Blends with low air permeability can be used in areas where high air or gas barrier properties are important, for example, food packaging materials. The water microfiltration and ultrafiltration also are considered for future application.

Author Contributions: Conceptualization, I.I. and I.F.; methodology, M.S., K.S., A.Z.; validation, I.I., I.F. and A.Z.; formal analysis, K.S., A.Z.; writing—original draft preparation, I.I.; writing—review and editing, I.F., A.Z. and T.J.; project administration, I.F. and T.J.; funding acquisition, T.J. All authors have read and agreed to the published version of the manuscript.

Funding: This research is funded by the Ministry of Education and Science, Republic of Latvia, Project "Integration of reliable technologies for protection against Covid-19 in healthcare and high-risk areas", 
Project No. VPP-COVID-2020/1-0004. The Article Processing Charge was kindly provided by the Latvian State Institute of Wood Chemistry Base financing source.

Institutional Review Board Statement: Not applicable.

Informed Consent Statement: Not applicable.

Data Availability Statement: Not applicable.

Conflicts of Interest: The authors declare no conflict of interest.

\section{References}

1. Silva, S.S.; Rodrigues, L.C.; Fernandes, E.M.; Reis, R.L. Fundamentals on biopolymers and global demand. In Biopolymer Membranes and Films; de Moraes, M.A., da Silva, C.F., Vieira, R.S., Eds.; Elsevier: Amsterdam, The Netherlands, 2020 ; pp. 3-34. [CrossRef]

2. Sukumaran, N.P.; Gopi, S. Overview of biopolymers: Resources, demands, sustainability, and life cycle assessment modeling and simulation. In Biopolymers and Their Industrial Applications; Thomas, S., Gopi, S., Amalraj, A., Eds.; Elsevier: Amsterdam, The Netherlands, 2021; pp. 1-19. [CrossRef]

3. Nakajima, H.; Dijkstra, P.; Loos, K. The Recent Developments in Biobased Polymers toward General and Engineering Applications: Polymers that are Upgraded from Biodegradable Polymers, Analogous to Petroleum-Derived Polymers, and Newly Developed. Polymers 2017, 9, 523. [CrossRef]

4. Rudnik, E. 10-Compostable Polymer Materials: Definitions, Structures, and Methods of Preparation. In Handbook of Biopolymers and Biodegradable Plastics; Ebnesajjad, S., Ed.; William Andrew Publishing: Boston, MA, USA, 2013; Volume 10, pp. 189-211. [CrossRef]

5. El-Enshasy, H.A. Filamentous Fungal Cultures-Process Characteristics, Products, and Applications. In Bioprocessing for ValueAdded Products from Renewable Resources; Yang, S.-T., Ed.; Elsevier: Amsterdam, The Netherlands, 2007; pp. 225-261. [CrossRef]

6. De Moraes, M.A.; Da Silva, C.F.; Vieira, R.S. Biopolymer Membranes and Films: Health, Food, Environment, and Energy Applications, 1st ed.; Elsevier: Amsterdam, The Netherlands, 2020; p. 654.

7. Nawawi, W.M.; Jones, M.; Murphy, R.J.; Lee, K.-Y.; Kontturi, E.; Bismarck, A. Nanomaterials Derived from Fungal Sources-Is It the New Hype? Biomacromolecules 2020, 21, 30-55. [CrossRef] [PubMed]

8. Nawawi, W.M.; Lee, K.-Y.; Kontturi, E.; Bismarck, A.; Mautner, A. Surface properties of chitin-glucan nanopapers from Agaricus bisporus. Int. J. Biol. Macromol. 2020, 148, 677-687. [CrossRef]

9. Jones, M.; Weiland, K.; Kujundzic, M.; Theiner, J.; Kählig, H.; Kontturi, E.; John, S.; Bismarck, A.; Mautner, A. Waste-Derived Low-Cost Mycelium Nanopapers with Tunable Mechanical and Surface Properties. Biomacromolecules 2019, 20, $3513-3523$. [CrossRef] [PubMed]

10. Yousefi, N.; Jones, M.; Bismarck, A.; Mautner, A. Fungal chitin-glucan nanopapers with heavy metal adsorption properties for ultrafiltration of organic solvents and water. Carbohydr. Polym. 2021, 253, 117273. [CrossRef] [PubMed]

11. Attias, N.; Reid, M.; Mijowska, S.C.; Dobryden, I.; Isaksson, M.; Pokroy, B.; Grobman, Y.J.; Abitbol, T. Biofabrication of Nanocellulose-Mycelium Hybrid Materials. Adv. Sustain. Syst. 2021, 5. [CrossRef]

12. Filipova, I.; Irbe, I.; Spade, M.; Skute, M.; Dābolina, I.; Baltina, I.; Vecbiskena, L. Mechanical and Air Permeability Performance of Novel Biobased Materials from Fungal Hyphae and Cellulose Fibers. Materials 2021, 14, 136. [CrossRef] [PubMed]

13. Manasseh, A.T.; Godwin, J.T.A.; Emanghe, E.U.; Borisde, O.O. Phytochemical properties of Ganoderma applanatum as potential agents in the application of nanotechnology in modern day medical practice. Asian Pac. J. Trop. Biomed. 2012, 2, S580-S583. [CrossRef]

14. Elkhateeb, W.; Daba, G.; Elnahas, M.; Thomas, P. Fomes fomentarius and Polyporus squamosus Models of Marvel Medicinal Mushrooms. Biomed. Res. Rev. 2020, 3. [CrossRef]

15. Habtemariam, S. Trametes versicolor (Synn. Coriolus versicolor) Polysaccharides in Cancer Therapy: Targets and Efficacy. Biomedicines 2020, 8, 135. [CrossRef]

16. Holban, A.M.; Grumezescu, A.M. Therapeutic Food. In Handbook of Food Bioengineering; Academic Press: Cambridge, MA, USA, 2018; Volume 8, p. 538.

17. Zajakina, A.; Vasilevska, J.; Zhulenkovs, D.; Skrastina, D.; Spaks, A.; Plotniece, A.; Kozlovska, T. High efficiency of alphaviral gene transfer in combination with 5-fluorouracil in a mouse mammary tumor model. BMC Cancer 2014, 14, 460. [CrossRef]

18. Kurena, B.; Vežāne, A.; Skrastina, D.; Trofimova, O.; Zajakina, A. Magnetic nanoparticles for efficient cell transduction with Semliki Forest virus. J. Virol. Methods 2017, 245, 28-34. [CrossRef] [PubMed]

19. Hutornojs, V.N.-O.B.; Kozlovska, T.; Zajakina, A. Comparison of ultracentrifugation methods for concentration of recombinant alphaviruses: Sucrose and iodixanol cushions. Environ. Exp. Biol. 2012, 10, 117-123.

20. Vasilevska, J.; Skrastina, D.; Spunde, K.; Garoff, H.; Kozlovska, T.; Zajakina, A. Semliki Forest virus biodistribution in tumor-free and 4T1 mammary tumor-bearing mice: A comparison of transgene delivery by recombinant virus particles and naked RNA replicon. Cancer Gene Ther. 2012, 19, 579-587. [CrossRef] [PubMed]

21. Ryvarden, L.M.I. Poroid Fungi of Europe, 2nd ed.; Fungiflora: Oslo, Norway, 2014; Volume 31, p. 455. 
22. Eisenman, H.C.; Casadevall, A. Synthesis and assembly of fungal melanin. Appl. Microbiol. Biotechnol. 2012, 93, 931-940. [CrossRef] [PubMed]

23. Xiao, B.; Wang, W.; Zhang, X.; Long, G.; Fan, J.; Chen, H.; Deng, L. A novel fractal solution for permeability and Kozeny-Carman constant of fibrous porous media made up of solid particles and porous fibers. Powder Technol. 2019, 349, 92-98. [CrossRef]

24. Gardner, D.J.; Oporto, G.S.; Mills, R.; Samir, M.A.S.A. Adhesion and Surface Issues in Cellulose and Nanocellulose. J. Adhes. Sci. Technol. 2008, 22, 545-567. [CrossRef]

25. Ling, S.; Chen, W.; Fan, Y.; Zheng, K.; Jin, K.; Yu, H.; Buehler, M.J.; Kaplan, D.L. Biopolymer nanofibrils: Structure, modeling, preparation, and applications. Prog. Polym. Sci. 2018, 85, 1-56. [CrossRef]

26. Aulin, C.; Gällstedt, M.; Lindström, T. Oxygen and oil barrier properties of microfibrillated cellulose films and coatings. Cellulose 2010, 17, 559-574. [CrossRef]

27. Priyadarshi, R.; Rhim, J.-W. Chitosan-based biodegradable functional films for food packaging applications. Innov. Food Sci. Emerg. Technol. 2020, 62, 102346. [CrossRef]

28. Jones, M.; Mautner, A.; Luenco, S.; Bismarck, A.; John, S. Engineered mycelium composite construction materials from fungal biorefineries: A critical review. Mater. Des. 2020, 187, 108397. [CrossRef]

29. Koubaa, A.; Koran, Z. Measure of the internal bond strength of paper/board. TAPPI J. 1995, 78, $103-111$.

30. Naik, K.; Kowshik, M. The silver lining: Towards the responsible and limited usage of silver. J. Appl. Microbiol. 2017, 123, 1068-1087. [CrossRef] [PubMed]

31. Shirasaki, N.; Matsushita, T.; Matsui, Y.; Murai, K. Assessment of the efficacy of membrane filtration processes to remove human enteric viruses and the suitability of bacteriophages and a plant virus as surrogates for those viruses. Water Res. 2017, 115, 29-39. [CrossRef]

32. Centers for Disease Control and Prevention, NIOSH. Use of Respirators and Surgical Masks for Protection Against Healthcare Hazards. Available online: https:/ /www.cdc.gov/niosh/topics/healthcarehsps/respiratory.html (accessed on 15 March 2021).

33. Martinez, M.J.A.; Olmo, L.M.B.D.; Benito, P.B. Antiviral Activities of Polysaccharides from Natural Sources. Stud. Nat. Prod. Chem. 2005, 30, 393-418. [CrossRef]

34. Shamshina, J.L.; Berton, P.; Rogers, R.D. Advances in Functional Chitin Materials: A Review. ACS Sustain. Chem. Eng. 2019, 7, 6444-6457. [CrossRef] 